\title{
A CONCEPTUAL UNDERSTANDING OF THE IMPACT OF EMPLOYEE TRAINING PROGRAMS ON JOB PERFORMANCE AND JOB SATISFACTION IN THE TELECOMMUNICATION COMPANIES IN MALAYSIA
}

\author{
Kumaran Kanapathipillai ${ }^{i}$ \\ Postgraduate Centre (PGC), \\ Management and Science University, \\ University Drive, Off Persiaran Olahraga, \\ 40100 Shah Alam, Selangor, \\ Malaysia
}

\begin{abstract}
:
Presently, many companies are confronted with tribulations while operating in a tempestuous business atmosphere; this is combined with the global pandemic, which is Covid-19, that has deteriorated the potency of the businesses. The telecommunication companies in Malaysia were also affected during these conditions. Therefore, a vital stratagem for the telecommunication firms to attain competitive advantage is through training programs conducted for all its employees throughout the various sections in the organization in order to beat this present obstacle. The objective of this research is to uncover if training influences job performance and job satisfaction which are two critical factors that guarantee the survival and growth of the telecommunication firms. Therefore, to realize the aim of this study, the survey technique is applied to cultivate a detailed profile which will be distributed to employees of three leading telecommunication cooperates in Malaysia. This study will use quantitative methods to generate empirical results and substantiations that responded to the research questions. The literature section scrutinized the areas of training, job performance, and job satisfaction to fill the gap and to determine the influence of training programs on job performance and satisfaction of employees. Therefore, the findings of this study could perhaps aid other corporations in Malaysia to instil continuous and well-planned training programs and not to take for granted the significance of training to improve job performance and satisfaction during the times of environmental turbulence. Thus, this could ensure that competitive strength is unceasingly maintained in the telecommunication firms in Malaysia.
\end{abstract}

i Correspondence: email kumar.erapintar@gmail.com 
A CONCEPTUAL UNDERSTANDING OF THE IMPACT OF EMPLOYEE TRAINING PROGRAMS ON JOB PERFORMANCE AND JOB SATISFACTION IN THE TELECOMMUNICATION COMPANIES IN MALAYSIA

Keywords: training, job performance, job satisfaction, employees, telecommunication companies

\section{Introduction}

This study was undertaken in three well-known telecommunication companies which were established in Malaysia to furnish the people of Malaysia with the latest telecommunication technologies and networks. Currently, these large corporate telecommunication companies are confronted with intense rivalry and crisis. Furthermore, the Covid-19 pandemic has made business more awful with the government's decision to initiate a lockdown. In this situation, either the companies exist by being better than their rivalries in terms of cost factors, or they could form a temporary monopoly gain that allows the companies to establish a price, rather than being constrained by the market condition. Therefore, monopoly is a brilliant measure the companies could adopt when there is severe government deregulation. This indicates that for long-term dominance in the market place, these companies could gain efficiency through job performance and job satisfaction of their employees. At the company level, there is an agreement that a more organised and comprehensive employee training was crucial to improving the employees' job performance and satisfaction. Therefore, training is viewed as a logical strategy to gain efficiency (Goldstein \& Ford, 2002) in (Khawaja \& Nadeem, 2013). Additionally, training is central in meeting the managerial challenges and in achieving the highest returns in venture investments according to (Fard \& Nda, 2013; Salah, 2016; Putra \& Chandra, 2017; Huang, 2019). Consequently, as a way to overcome these tempestuous challenges, the corporate leaders of these telecommunication corporations comprehend that training as their most significant strategy to enhance the job performance and the job satisfaction of their employees.

Furthermore, the leaders of these telecommunication firms concede that training is the most suitable method to amplify workers' job performance and job satisfaction. Thus, this has resulted as the best motive for the author to analyse as to whether the training programs conducted was significant for the job performance and job satisfaction of the employees in these three telecommunication companies. Many researchers, such as (Nassazi, 2013; Afroz, 2018) have attempted to understand the quantifiable outcomes of training conducted in organisations. It was noted that generally, training programs are measured at the reaction level, for instance, the research conducted by (Lee \& Ming, 2007). In some cases, researchers such as (Rajeev et al., 2009) only researched at the learning level, such as pre-test and post-test of the training program. Regrettably, these studies only evaluate trainees' feelings and knowledge acquired; they do not weigh the significance of the emotions, behaviours and knowledge that generates job performance and job satisfaction. According to (Karim et al., 2019; Sandamali et al., 2018; Sanchez et al., 2003) the outcome, that is significant to a firm that invests in training programs are related to its organisational performance and productivity which the organisation will be able to achieve through its employees' job performance and job satisfaction. 
The central aim of this study is to scrutinise the associations between the independent variable (training program conducted) and the dependent variables job performance (Mahmood et al., 2018; Swaminathan et al., 2019) and job satisfaction (Cascio, 1995; Latif, 2012; Imran \& Tanveer, 2015; Ahmed et al., 2016; Sri Dhurgah et al., 2018).

This study can be extremely valuable for scholars as well as practising administrators and directors who foresee that training programs provided to employees are a strategy that would allow the employees and the organisation to get ready. They may also be able to overcome the tribulations that exist in the business atmosphere, especially when businesses are reopened after the long lockdown period due to the Covid-19 pandemic. The newest shreds of evidence from this study could be an inspiration to practising administrators and directors to amplify their employee's job performance and job satisfaction which in turn would lead to organisational performance and enhance its productivity through well-planned training programs. As a result, positive social change could emerge if the independent variable, which are the training programs conducted in the telecommunication companies becomes significant for the dependent variables which are employees' job performance and job satisfaction.

\section{Literature Review}

This literature review is vital to furnish the present situation on knowledge and matters of interest to the research. Numerous significant and relevant theories and ideas are illuminated in this section.

\subsection{Training}

A business organisation could achieve its strengths when its employees attain performance and satisfaction in their jobs. To gain the highest level of performance and satisfaction, the employees must be subjected to proper training as elucidated by (Kapur, 2018; Rodriguez, \& Walters, 2017; Salah, 2016; Mozael, 2015; Kum et al., 2014; Maimuna \& Fard, 2013). Additionally, training has been acknowledged by many research scholars and managers as the main ingredient for the success of an organisation and its management (McDowall \& Saunders, 2010). Training at its best is an array of methods intended to uninterruptedly create knowledge skills and abilities as well as improve organisational logics, and this is inclusive of the training itself (Blanchard \& Thacker, 1999; Vasudevan, 2014; Mozael, 2017; Sri Dhurgah et al., 2018; Huang, 2019). Based on scholars, (Frost, 2019; Dessler, 2010; Cole, 2002), training is a learning process to procure improved expertise and knowledge that is required to accomplish tasks in an organisation. Furthermore, (Engetou, 2017) mentions that training leads to higher productivity (Osborne \& Hammoud, 2017) as well as safety in the organisational manoeuvres (Katz, 2020). Besides, (Vasudevan, 2014; Singh and Mohanty, 2012; Tzafrir, 2016; Nunvi, 2006) mention that, training is employees' involvement that is well thought out in order to generate higher employee performance. This means that it enriches an 
A CONCEPTUAL UNDERSTANDING OF THE IMPACT OF EMPLOYEE TRAINING PROGRAMS ON JOB PERFORMANCE AND JOB SATISFACTION IN THE TELECOMMUNICATION COMPANIES IN MALAYSIA

employee's efficiency and eventually yields organisational success (Alnawfleh,2020). On the other hand, (Lerman et al., 1999; Billikopf, 2003), indicate that when training is provided to the employees' of an organisation time is just wasted and results in adverse consequences whereby the employees need to adapt and struggle with the new tasks handed to them after the training is completed. This belief is contradicted by (David et al., 2005; Jenks et al., 2007) who elucidate that employees can gain new knowledge, expertise and capabilities through well organised and planned training programs. Additionally, the knowledge imparted during training by the trainer and the experience shared with other trainees' may eventually enhance job performance (Karim et al., 2019) and create job satisfaction (Gobal et al., 2018). Therefore, the need for training programs in large corporate organisations is to bring about changes in the employees' attitudes, performance, motivation and satisfaction as well as their perspective of the organisations (Sri Dhurgah et al., 2018; Huang, 2019). This means that it is even more critical when new employees are recruited, as they are expected to make perfections in the performance of their jobs. Training programs not only create awareness of the organisation's goals but also generates a sense of job satisfaction for new employees (Varshney, 2019). Additionally, well-planned training programs also develop positive thinking and encourages employees to initiate changes to overcome challenges and finally enhances their performance and creates greater satisfaction throughout their career (Karim et al., 2019; Swaminathan et al., 2019; Sandamali et al., 2018).

Training programs are imperative for some novice employees in large corporate organisations who are unaware of the required performance level in their jobs. Through training programs, the employees will be able to procure absolute knowledge and skills thus building and strengthening precise areas of their jobs which will ultimately create confidence, performance and satisfaction in their careers (Kapur, 2018). Therefore, corporate organisations will be able to operate much more competently. The organisation will then be able to achieve its vision and generate profits when the trained employees of the organisation display high levels of performance (Nassazi, 2013; Sandamali et al., 2018; Swaminathan et al., 2019) and continuously exhibit satisfaction (Tzafrir, 2016; Huang, 2019).

\subsection{Job Performance}

An individual's performance is extremely vital for an organisation's well-being. When performance in tasks are achieved, an employee will feel the attainment of self-efficacy and mastery of their skills and knowledge. Many scholars agree that job performance is a multi-dimensional theory. This means that when an employee is subjected to action at work, whereby the action here is training. Then this action translates to performance (Afroz, 2018). This can be supported by (Asim, 2013; Sandamali et al., 2018; Karim et al., 2019) who elucidate that an employee's job performance is dependent primarily on the training program they received. Brown (2008); Baldwin (2008) and Sila (2014) has termed job performance as how applicably an employee accomplishes assignments as well as the attitude with which the employee performs the activities excellently and competently. 
A CONCEPTUAL UNDERSTANDING OF THE IMPACT OF EMPLOYEE TRAINING PROGRAMS ON JOB PERFORMANCE AND JOB SATISFACTION IN THE TELECOMMUNICATION COMPANIES IN MALAYSIA

Additionally, (Nassazi, 2013; Huang, 2019) mention that job performance is the effect of an individual's scheme, result, association, and triumphs. Furthermore, (Nassazi, 2013; Sandamali et al., 2018; Swaminathan et al., 2019) has revealed that an employee becomes extremely stimulated when there is an enhancement in the level of efficiency. Additionally, according to (Sandamali et al., 2018; Swaminathan et al., 2019), the unpretentious way of utilising the latest technologies has demonstrated the existence of job performance. This account can be further reinforced by research undertaken by (Halawi \& Haydar, 2018) in Lebanon that training programs executed well in organisations will inspire the etiquette of workers and their aptitudes to accomplish the tasks competently and industriously. Another finding which supports the notion that training has a strong positive relationship with employee performance is research conducted in Sri Lanka in the apparel organisations by (Sandamali et al., 2018). To corroborate this even further, (Diamantidis \& Chatzoglou, 2018) also have found that training has become very significant for the achievement of job performance. This will infuse the essential proficiencies desirable to embark on various assignments assigned by the management of an organisation. Contradictory to these findings, a research conducted in Britain by (Jones et al., 2008) uncover that the training programs conducted and its relationship to employee performance is complicated. According to (Jones et al., 2008), the performance of the employees depends on the types and volume of training programs provided. Another research can further substantiate this finding conducted more recently in Malaysia in some private companies by (Shafiq \& Hamza, 2017). They have discovered that training has an insignificant impact on employee performance. Thus, there is a gap that needs to be addressed and filled on the significance of training on job performance.

\subsection{Job Satisfaction}

Job satisfaction is a concoction of the positive and negative emotions that employees have towards their job, and it is a subjective viewpoint of the feeling that employees have about their job (Cherif, 2020; Abuhashesh et al., 2019; Robbins \& Judge, 2013). Employees' sense of accomplishments and triumph of the assignments given by the management is considered as job satisfaction (Fontova-Almato, 2020). When an employee attains job satisfaction, this precedes to a promotion, recognition, higher salary which eventually steers to a sense of fulfilment (Zalk et al., 2016; Anwar \& Shukur, 2015). Based on (Latif, 2012; Sharma \& Chandra, 2013; Varshney, 2019), job satisfaction is the enviable or unenviable sensation that an employee has about his or her profession. This is a, very personal matter, as satisfying elements for one employee might not act as a pleasing feature for another employee, according to (Rowden \& Conine, 2005). Additionally, (Maurer and Lippstreu, 2008) mention that one of the functions of human capital that aids in shifting workers personality is the support in terms of personal development. This must be enforced by the administration or corporate leaders as it precedes to employees' job satisfaction. Besides, (Garcia-Bernal et al., 2005; Vasudevan, 2014; Tzafrir, 2016; Huang, 2019) elucidate that training defines personnel satisfaction which enhances 
efficiency and subsequently lowers dissatisfaction in jobs. Latif (2014) discovered that for an organisation to realise organisational performance, it has to undertake the essential steps that elevate the job satisfaction of individuals in an organisation. According to (Gazioglu \& Tansel, 2006) the most efficient measure is by conducting training programs which precede to the job satisfaction of the individuals in the company. Additionally, to reinforce this account, research undertaken in America indicates that training programs heightened the competencies and impetus of the employees. Subsequently, this increased the job satisfaction of workers (Community Banker, 2001). Furthermore, (SiebernThomas, 2005) researched thirteen countries in the European Community Household Panel and unearthed that the relationship between workplace training and job satisfaction is positively correlated. A more recent research conducted by (Abuhashesh et al., 2019) in Jordan further revealed that there is a positive relationship between training and job satisfaction. This discovery is reinforced by (Vasudevan, 2014) who elucidated that training programs conducted amplifies job satisfaction of workers. Therefore, these shreds of evidence suggest that companies which disregard training programs as a strategy will not be able to realise an ideal level of workers' job satisfaction and additionally would be subjected to high dissatisfaction, low morale and finally high turnover. In contrast, research conducted by (He et al., 2015) illustrates that the relationship between training and job satisfaction is not strong. Another contradicting finding was a study conducted by (Yi An, 2016) in the United States of America, who has discovered that there was not enough evidence to prove that there is a significant relationship between training and job satisfaction. Thus, there is a gap that needs to be addressed and filled on the significance of training on job satisfaction.

\section{Conclusion}

The main motive of this study was to ascertain the relationship between the training programs conducted in three prominent telecommunication companies in Malaysia and its effect on job performance and job satisfaction. The findings of this study will help to narrow the gaps presented in the literature. From the literature, it is evident that training has an impact on the employees' job performance and job satisfaction as found in various researches conducted previously by (Fontova-Almato, 2020; Asim, 2013; Sandamali et al., 2018; Karim et al., 2019; Latif, 2012; Sharma \& Chandra, 2013; Varshney, 2019). This enlightens by exposing to the researchers that all workers should undertake the essential training programs which would equip them with the proper knowledge, aptitudes and mindsets, so that job performance and job satisfaction are realized and heightened as elucidated by (Fontova-Almato, 2020; Diamantidis \& Chatzoglou, 2018; Vasudevan, 2014). On the other hand, there are also contradicting remarks and findings with regards to the outcome of training, which indicates the insignificance of training towards job performance and job satisfaction. As there exist conflicting facts about the impact of training on job performance and job satisfaction, thus, it is crucial to conduct this research to find out whether the effects of training is significant to the job performance and job 
satisfaction of the employees in the telecommunication companies in Malaysia. If it was found to be substantial, then the employees should be unceasingly exposed to training programs to attain personal advancement in their organization. This will ensure the employees' performance standards and their morale is high as mentioned by (Huang, 2019). Additionally, if there is proof from this study that training effects and are significantly correlated to job performance and job satisfaction. As such, the telecommunication companies in this study could continuously instil various training programs to subsist and succeed even during times of trials such as during the Covid-19 pandemic currently encountered by many companies around the world inclusive of Malaysian cooperations.

\subsection{Expected Contributions of the Study}

The consequences of training programs conducted in organizations cannot be undervalued (Katz, 2020; Fontova-Almato, 2020; Abuhashesh et al., 2019). Training programs are needed at all level in the organization because it brings about an enhancement in employees' knowledge and skills; which in turn creates performance, satisfaction as well as higher productivity (Frost, 2019; Engetou, 2017; Huang, 2019; Karim, 2019).

This research will be beneficial for academics, managers, trainers, and human resource practitioners to understand how training could strengthen employees' performance as well as instil satisfaction which in turn enhances the organizational performance. Additionally, this research is vital because various organizations in this modern and turbulent business environment are endeavouring to attain a competitive edge and there is no way this can be achieved without increasing employees' competencies, capabilities, skills and knowledge through sufficient training programs. Furthermore, this research outcomes will help the management of not only the telecommunication companies but also companies in various other business sectors to identify the effects of training on employees' performance and satisfaction hence establish the regions where perfections through training programs are needed. It will also help the managers in planning for the enhancement and execution of effective and efficient training needs that will lead to increased performance, satisfaction and productivity for both the employees and the organization as elucidated by (Swaminathan et al., 2019; Sandamali et al., 2018; Salah, 2016; Putra \& Chandra, 2017; Huang, 2019). The researchers of this study are optimistic that the contribution of this research will be of great value to academics, managers, trainers and leaders or anyone who is fascinated in the topic of training and learning. Moreover, the findings of this research may become a foundation for a theoretical framework for future heuristic studies on training. Besides, this study may also become a cradle of revelation to various academics and trainers in developing a practical approach to training.

Finally, it can be deduced that the findings from this research and the corroborating literature will contribute tremendously to the employees of the telecommunication companies, its trainers, managers and academics in terms of 
presenting valuable inputs and knowledge of exactly how and why training is substantial to achieving job performance and job satisfaction and in turn bringing about social change.

\section{Conflict of Interest}

The author of this manuscript declares that there is no connection with or involvement in any firms or entity with any financial or non-financial gains which could manipulated its results such as educational grants, honoraria, employment, consultancies, stock ownership, equity interest, personal or professional relationships. As the author, the researcher affirms that this manuscript is novel research and has not been published previously, and it is not presently being considered for publication elsewhere.

\section{About the Author}

Kumaran Kanapathipillai holds a PhD in Business/Management by the Management and Science University (Malaysia). He is a freelance and visiting professor in Management and Marketing subjects in several local and international universities. He supervises and assesses Masters and $\mathrm{PhD}$ thesis. He conducts training on entrepreneurship, creative problem solving and project management in various industries. He is also the founder and director of an educational institution in Malaysia for A Levels program. His main areas of interest and research is on contemporary entrepreneurship, management, and marketing. He is also a peer reviewer for Sage Publications.

\section{References}

Abuhashesh, M., Al-Dmour, R., \& Masadeh, R. (2019). Factors that Affect Employees Job Satisfaction and Performance to Increase Customers' Satisfaction. Journal of Human Resources Management Research, 2019(2019): 2-23.

Afroz, N. N. (2018). Effects of Training on Employee Performance: A Study on Banking Sector, Tangail Bangladesh. Global Journal of Economics and Business, 4(1): 112123.

Ahmed, R., Ahmad, N., \& Channar, Z. (2016). Relationship between training \& development and Performance of Business Schools' Faculty. Conference: 9th Annual International Conference of Education, Research and Innovation (ICERI2016), Volume: ISBN: 978-84-617-5895-1.

Alnawfleh, S. H. (2020). Effect of Training and Development on Employee Performance in the Aqaba Special Economic Zone Authority. Journal of Business and Management, 8(1): 20-34.

Anwar, G., \& Shukur, I. (2015). The Impact of Training and Development on Job Satisfaction: A Case Study of Private Banksin Erbil. International Journal of Social Sciences \& Educational Studies, 2(1): 65-72. 
A CONCEPTUAL UNDERSTANDING OF THE IMPACT OF EMPLOYEE TRAINING PROGRAMS ON JOB PERFORMANCE AND JOB SATISFACTION IN THE TELECOMMUNICATION COMPANIES IN MALAYSIA

Asim, M. (2013). Impact of motivation on employee performance with effect of training: Specific to education sector of Pakistan. International Journal of Scientific and Research Publications, 3(9): 1-9.

Baldwin, K. (2008). Managing Employee Performance in Seven Steps. Baldwin Kieran Billikopf, G. (2003). Helping Workers Acquire Skills. Labour Management in Agriculture: Cultivating Personnel Productivity, 51-58.

Blanchard, P. N. \& Thacker, J. W. (1999). Effective Training Systems, Strategies and Practices. Prentice-Hall Inc.

Brown, E. (2008). Dimensions of Transformational leadership and relationship with employee performance in hotel front desk staff. ProQuest Information and Learning Company. IOWA.

Cascio W. F. (1995). Managing Human Resources. New York: McGraw Hill Inc. 1995; 245. Chauhan, R. (2018). Impact of Training and Development on Employee Performance and Productivity with Reference to Indian Banking Sectors. International Journal of Engineering Research and Management Technology, 5(2): 11-19.

Cherif, F. (2020). The Role of Human Resource Management Practices and Employee Job Satisfaction in Predicting Organizational Commitment in Saudi Arabian Banking Sector. International Journal of Sociology and Social Policy, Emerald Publishing Limited 0144-333X DOI 10.1108/IJSSP-10-2019-0216.

Cole, G. A. 2002 Personnel and Human Resource Management Practice, 5th edition.

Community Banker (2001). What Drives Employee Satisfaction? Community Banker.

David, A. F., Scott, J. S., Nancy, B. J. \& Michelle, K. D. (2005). Employee Commitment and Organizational Policies. Management Decision, 43(2): 205-218.

Dessler, G. (2010). Human Resource Management, The Strategic Role of Human Resource Management. New Jersey, NJ: Prentice Hall Inc.

Diamantidis, A., \& Chatzoglou, P. (2018). Factors Affecting Employee Performance: An Empirical Approach. International Journal of Productivity and Performance Management. 68(1): 173-190.

Engetou, E. (2017). The Impact of Training and Development on Organisational Performance. Thesis. Centria University of Applied Sciences. Retrieved from https://www.theseus.fi/bitstream/handle/10024/133220/Engetou\%20Enga..pdf

Fard, R. Y., \& Nda, M. M. (2013). The Impact of Employee Training and Development on Employee Productivity. Global Institute for Research \& Education. Global Journal of Commerce \& Management Perspective, 2(6): 90-93.

Fontova-Almato, A., Suner-Soler, R., Salleras-Duran, L., Bertran-Noguer, C., CongostDevesa, L., Ferrer-Padrosa, M., \& Juvinya-Canal, D. (2020). Evolution of Job Satisfaction and Burnout Levels of Emergency Department Professionals During a Period of Economic Recession. International Journal of Environmental Research and Public Health, 17: 2-12.

Frost, S. (2019). The Importance of Training and Development in the Workplace. Retrieved from https://smallbusiness.chron.com/importance-trainingdevelopment-workplace-10321.html 
A CONCEPTUAL UNDERSTANDING OF THE IMPACT OF EMPLOYEE TRAINING PROGRAMS ON JOB PERFORMANCE AND JOB SATISFACTION IN THE TELECOMMUNICATION COMPANIES IN MALAYSIA

Garcia-Bernal, J., Gargallo-Castel, A., Marzo-Navarro, M., \& Rivera-Torres, P. (2005). Job Satisfaction: Empirical Evidence of Gender Differences. Women in Management Review, 20(4): 281-287.

Gazioglu, S., \& Tansel, A. (2006). Job Satisfaction in Britain: Individual and Job-Related Factors. Applied Economics, 38(10): 1165-1170.

Gobal, Sri \& Hassan, Ayyub \& Gobal, Shashveena \& Baker, Rogis \& Yunus, Wan \& Norazman, Irmawati (2018). The Effect of Training on Job Satisfaction. Conference Paper. The International Conference of Social Sciences and Humanities 2018, University Technology Malaysia.

Halawi, A., \& Haydar, N. (2018). Effects of Training on Employee Performance. International Humanities Studies, 5(2): 23-36.

He, P., Findley, H., \& Wheatley, R. (2015). The Effects of Training on Job Satisfaction and Service Quality Among Temporary Employees: The Mediating Role of Affective Commitment. Journal of Management and Marketing Research, 21: 1-17.

Huang, W. R. (2019). Job Training Satisfaction, Job Satisfaction, and Job Performance. IntechOpen, DOI:10.5772/intechopen.89117. Retrieved from https://www.intechopen.com/online-first/job-training-satisfaction-jobsatisfaction-and-job-performance.

Imran, M., \& Tanveer, A. (2015). Impact of Training \& Development on Employee Performance: Performance in Banks in Pakistan. European Journal of Training and Development Studies. 3(1): 23-33.

Jenks, D. A., Carter, J. S. and Jenks, C. A. (2007). Command Staff Leadership Training and Job Commitment in the LADP. Southwest Journal of Criminal Justice, 4(2): $106-$ 119.

Jones, M. K., Jones, R. J., Latreille, P. L., \& Sloane, P. J. (2008). Training, Job Satisfaction and Workplace Performance in Britain: Evidence from WERS 2004. IZA Discussion Paper Series No. 3677. Retrieved from http://ftp.iza.org.

Kapur, R. (2018). Designing and Implementation of Training Programs in Organizations. University of Delhi.

Karim, M. M., Choudhury, M. M., \& Latif, W. B. (2019). The Impact of Training and Development on Employees' Performance: An Analysis of Quantitative Data. Nobel International Journal of Business and Management Research, 3(2): 26-31.

Katz, E. (2020). What is Workplace Safety Training and Why Do We Need It? Retrieved from https://connecteam.com/workplace-safety-training-need

Khawaja \& Nadeem (2013). Training and Development Program and its Benefits to Employee and Organisation: A Conceptual Study. European Journal of Business and Management, 5(2): 2-8.

Kum, F. D., Cowden, R. \& Karodia, A. M. (2014). The Impact of Training and Development on Employee Performance: A Case Study of ESCON Consulting. Singaporean Journal of Business Economics and Management Studies, 3(3):72-104 
A CONCEPTUAL UNDERSTANDING OF THE IMPACT OF EMPLOYEE TRAINING PROGRAMS ON JOB PERFORMANCE AND JOB SATISFACTION IN THE TELECOMMUNICATION COMPANIES IN MALAYSIA

Latif, K. F. (2012). An integrated model of training effectiveness and satisfaction with employee development interventions, Industrial and Commercial Training, 44(4) pp. $211-222$.

Lerman, R. I., McKernan, S., \& Riegg, S. (1999). Employer-Provided Training and Public Policy, The Urban Institute, Washington D. C., 3-41.

Lee, S. H., \& Ming, J. A. (2007). Effective Reaction Evaluation in Evaluating Training Programs. Purposes and Dimension Classification. Wiley Online Library, 38(8). Retrieved from https://doi.org/10.1002/pfi.4140380808.

Maimuna, M. N., \& Fard, Y. R. (2013). The Impact of Employee Training and Development on Employee Productivity. Global Journal of Commerce \& Management Perspective 2(6): 92-93.

Maurer, T., \& Lippstreu, M. (2008). Who Will Be Committed to an Organisation that Provides Support for Employee Development? Journal of Management Development, 27(3): 330-345.

McDowall, A. and Saunders, M. N. K. (2010). UK Manager's Conceptions of Training and Development. Journal of European Industrial Training, 34: 610-629.

Mohmood, M., Hee, O. C., Yin, O. S., \& Hamli, M. S. H. (2018). The Mediating Effects of Employee Competency on the Relationship Between Training Functions and Employee Performance. International Journal of Academic Research in Business and Social Sciences, 8(7): 665-675.

Mozael, B. M. (2015). Impact of Training and Development Programs on Employee Performance. International Journal of Scientific and Research Publications, 5(11): $38-41$.

Nassazi, A. (2013). Effects of Trainings on Employee Performance: Evidence from Uganda. Business Economics and Tourism, University of Applied Sciences. Retrieved from https://core.ac.uk/download/pdf/38098025.pdf

Nunvi, G. P. (2006). Business Organisation and Management, 3rd Edition

Osborne, S. \& Hammoud, M. S. (2017). Effective Employee Engagement in the Workplace. International Journal of Applied Management and Technology, 16(1): 51-66.

Pham, L. T. M. (2018). A Review of Key Paradigms: Positivism, Interpretivism \& Critical Inquiry, School of Education, The University of Adelaide, http://researchgate.net.

Putra, T. R. I., \& Chandra D. R. (2017). The Analysis of Effectiveness of Education, Training and Motivation on Work Productivity and its Impact on the Performance of Civil Service of Personnel, Education and Training Agency, (BKPP), The Province of Aceh, Indonesia. Journal of Resources Development and Management, 29:2017. 32-36.

Rajeev, P., Madan, M. S., \& Jayarajan, K. (2009). Revisiting Kirkpatrick's Model: An Evaluation of an Academic Training Course. Current Science, 96(2): 2-270.

Robbins, S., \& Judge, T. (2013). Organizational Behaviour (15th ed.). USA: Pearson Prentice Hall. 
A CONCEPTUAL UNDERSTANDING OF THE IMPACT OF EMPLOYEE TRAINING PROGRAMS ON JOB PERFORMANCE AND JOB SATISFACTION IN THE TELECOMMUNICATION COMPANIES IN MALAYSIA

Rodriguez, J. \& Walters, K. (2017). The Importance of Training and Development in Employee Performance and Evaluation. Worldwide Journal of Multidisciplinary Research and Development, 3(10): 206-212.

Rowden, J., \& Conine, T. Jr. (2005). The Impact of Workplace Learning on Job Satisfaction in Small US Commercial Banks. Journal of Workplace Learning, 17(4): 217-228.

Salah, M. R. A. (2016). The Impact of Training and Development on Employees Performance and Productivity. International Journal of Management Sciences and Business Research, 5(7): 36-43.

Sanchez, A. A., Aragon, M., \& Sanz Valle, R. (2003). Effect of Training on Business Results. International Journal of Human Resource Management, 14: 954-976.

Sandamali, J. G. P., Padmasiri Dinithi, M. K., Mahalekamge, W. G. S., \& Mendis, M. V. S. (2018). The Relationship Between Training and Development and Employee Performance of Executive Level Employees in Apparel Organisations. International Inventions of Scientific Journal, 2(1): 12-16.

Saunders, M., Lewis, P., \& Thornhill, A. (2003). Research Methods for Business Students (3rd Ed.) Harlow, England: Financial Times Prentice Hall.

Shafiq, S., \& Hamza, S. M. (2017). The Effect of Training and Development on Employee Performance in Private Company, Malaysia. International Journal of Education, Learning and Training, 2(2): 42-51.

Sharma, M., \& Chandra, S. (2013). Managerial Training and Development in Malaysia, Malaysian Institute of Management, Kuala Lumpur.

Siebern-Thomas, F. (2005). Job Quality in European Labour Markets, in Bazen, S., Lucifora, C., \& Salverda, W. (Eds.), Job Quality and Employer Behaviour, Palmgrave Macmillan, Basingstoke, Hants, 32-60.

Sila, A. K. (2014). Relationship Between Training and Performance: A Case Study of Kenya Women Finance Trust Eastern Nyanza Region, Kenya. European Journal of Business and Social Sciences, 3(1): 97-115.

Singh, R. \& Mohanty, M. (2012). Impact of Training Practices on Employee Productivity: A Comparative Study. Inter Science Management Review, 2(2): 88-91.

Sri Dhurgah, D. V. G., Hassan, A., Shashveena, T.V.G., Baker, R., Yunus, W., \& Norazman, I. (2018). The Effect of Training on Job Satisfaction: A Review Paper. Management Faculty, University Teknology Malaysia, ISBN 978-967-15950: 137140.

Swaminathan, S., Abirami, M. J., Mahalakshmi \& Ikram, M. (2019). Effectiveness of Training on Competency Development. Galore International Journal of Health Sciences \& Research, 4(2): 28-31.

Tzafrir, J. (2016). The Effect of Individual Human Resource Domains on Financial Performance. International Journal of Human Resource Management, 16(5): 678699.

Varshney, D. (2019). Employees' Job Involvement and Satisfaction in a Learning Organisation: A Study in India's Manufacturing Sector. Wiley Online Library. https://doi.org/10.1002/joe.21983. 
Vasudevan, H. (2014). Examining the Relationship of Training on Job Satisfaction and Organisational Effectiveness. International Journal of Management and Business Research, 4(3): 186-200.

Yi An Lu (2016). An Exploration of Training and Job Satisfaction: An Examination of H1B Foreign Workers in a Southern State in the United States. Masters Thesis. Retrieved from http://repository.lib.ncsu.edu/bitstream/handle/1840.16/10879/etd.pdf?

Zalk, M., Bensch, D., Maab, U., Schult, V., Vogel, M., \& Buhner, M. (2016). Big Five Facets as Predictors of Job Training Performance: The Role of Specific Job Demand. Learning and Individual Differences, 29: 2-6. 
Creative Commons licensing terms

Authors will retain copyright to their published articles agreeing that a Creative Commons Attribution 4.0 International License (CC BY 4.0) terms will be applied to their work. Under the terms of this license, no permission is required from the author(s) or publisher for members of the community to copy, distribute, transmit or adapt the article content, providing a proper, prominent and unambiguous attribution to the authors in a manner that makes clear that the materials are being reused under permission of a Creative Commons License. Views, opinions and conclusions expressed in this research article are views, opinions and conclusions of the author(s).Open Access Publishing Group and European Journal of Management and Marketing Studies shall not be responsible or answerable for any loss, damage or liability caused in relation to/arising out of conflict of interests, copyright violations and inappropriate or inaccurate use of any kind content related or integrated on the research work. All the published works are meeting the Open Access Publishing requirements and can be freely accessed, shared, modified, distributed and used in educational, commercial and non-commercial purposes under a Creative Commons Attribution 4.0 International License (CC BY 4.0). 